\title{
Feedback between societal change and hydrological response in Wadi Natuf, a karstic mountainous watershed in the occupied Palestinian Westbank
}

\author{
CLEMENS MESSERSCHMID
}

Institute of Hydrology, University of Freiburg, Fahnenbergplatz, D-79098 Freiburg, Germany and PO Box 38383, Jerusalem 91383, Israel

clemensmesserschmid@yahoo.de

\begin{abstract}
Runoff observations with high spatial and temporal resolution before, during and since the Intifada in the occupied Palestinian West Bank, allow for new insights into the feedback between changing social systems and hydrological response under changing land forms. The lack of land control and infrastructure, movement restrictions and tight closure regimes, intensive settlement expansion and mushrooming unregulated solid waste dump-sites impact on runoff generation, groundwater recharge, flow patterns and rising water quality concerns. Long-term monitoring results from a $105 \mathrm{~km}^{2}$ Mediterranean climate catchment are presented. More research will strengthen these linkages. Changing socio-hydrological context of land sovereignty and equitable water rights remain paramount for addressing the chronic water crisis, establishing more symmetrical access and sustainable management of the shared water resources.
\end{abstract}

Key words Karstic mountainous watershed; land forms; WAB; terraces; rain-fed farming; mobility; sovereignty and control over open landscape; sanitation; solid waste; severely restricted water access

\section{INTRODUCTION}

The impact of reduced water resource availability on society and political conflict has been widely published (World Bank 2009). Many reports such as by Hareuveni and Stein (2011) and Koek (2013) analyse how water access restrictions feedback on socio-economy, settlement distribution and population migration. Much less attention has been paid to the question of how societal change and conflict impact and feedback on water resources, hydrology and hydrogeology.

Hydrological linkages where storm runoff is affected by anthropogenic alterations of land use patterns have been observed in the region (Kronaveter et al. 2001). In the wider Wadi Natuf, existing research focused on natural runoff generation and urbanisation impacts on a plot-size or small local scale and individual events or seasons (Lange et al. 2002, 2003a,b, 2004, Steinmann 2010). Now, for the first time, longer term monitoring of rainfall and runoff under spatially and temporally high resolution, as well as associated land forms and land use, has been conducted on a larger sub-regional scale $\left(105 \mathrm{~km}^{2}\right)$ in the occupied Palestinian Territories and allows for new insights into the mutual feedback between hydrology and society ${ }^{1}$.

\section{The physical basis}

Wadi Natuf is a $105 \mathrm{~km}^{2}$ surface catchment in the Palestinian West Bank, $4 \mathrm{~km}$ northwest of Ramallah. It stretches from the central mountains eastwards towards the 1949 Armistice Line ("Green Line") to Israel. In November-May, Mediterranean rain follow a pronounced monotonous gradient from $507 \pm$ $97 \mathrm{~mm} /$ year at Ne'alin in the West (Fig. 1(a)) to $650 \pm 141 \mathrm{~mm} /$ year at Bir Zeit in the East (Fig. 1(b)) with an area average of $591 \pm 116 \mathrm{~mm} /$ year (2003/04-2012/13). The maximum range lies between $383 \mathrm{~mm}$ at Ne'alin (2009/10) and $884 \mathrm{~mm}$ at Bir Zeit (2011/12). Spatial variability was low, with an average of $577 \mathrm{~mm} /$ year $\pm 50 \mathrm{~mm} /$ year (2003/04-2011/12) between the stations. Peak rain reached $114 \mathrm{~mm} / \mathrm{d}$ in Bir Zeit on 2 April 2006 (up to $11.4 \mathrm{~mm}$ in 5 minutes at 07:50 h). Wadi Natuf, a crucial recharge area of the Western Aquifer, has surprisingly low net runoff outflow coefficients at $\sim 1 \%$ only $\left(\sim 0.5 \mathrm{hm}^{3} /\right.$ year). Recharge coefficients locally reach well beyond $40 \%$ in the mountains.

\footnotetext{
${ }^{1}$ The monitoring campaign started in 2003 as part of the project, "The Sustainable Use of West Bank and Gaza Aquifers", by Palestinian Water Authority, University of Newcastle upon Tyne and British Geological Survey (SUSMAQ 2002). After 2005, the original field instrumentation - also including weather stations, spring flow, soil moisture and groundwater level and salinity monitoring - was only slightly modified.
} 


\section{The socio-political basis}

Wadi Natuf appears as a pristine rural area with large natural open spaces between the 20 villages, due to Israel's strictly imposed military restrictions on Palestinian residential construction and village expansion. However, Jewish civilian settlements and military camps expand rapidly and consume vast land resources, due to their loose build-up with often less than $1 \%$ of the population density of the adjacent Palestinian villages. So far, nine settlements and various "outposts" were implanted in Wadi Natuf, with a particular settlement cluster in mid to upper Wadi Natuf (bottom centre in Fig. 1(b)) under permanent unabated construction. Figure 1(b) shows the planned settlement expansion scheme in 2003 and the then proposed route of the separation wall. Not all was realised since its route was altered under international pressure, but the settlement expansion and de facto takeover map gives a fair representation of their mid-term targets - an uninterrupted zone of illegal Jewish settlement in the heart of the Palestinian West Bank. The emerging deep impact of these "settler bubbles" can already be observed and will be presented in this article.

Settlement expansion was also carried out in a "softer" approach, yet on a far greater scale, by erecting "security fences", especially in 2003 and 2004, along generous perimeters around the handful of caravans and houses. In parallel, Israel constructed its illegal and impenetrable separation wall through lower Wadi Natuf. Both systems aim and result in creating vast no-go zones for Palestinians, a form of silent takeover. This fundamentally alters the land use. Over the years 20022012, it could be observed how step-wise, olive groves, now within settlement perimeters and cluster areas, fell into disarray, grew over with weeds, and terraces started to crumble; the former prime recharge areas became more receptive to runoff generation.

Hand in hand with settlement expansion goes the construction of settler highways at an astonishing pace, way beyond current traffic needs. During the height of the second Intifada (20022004), these roads were reserved for exclusive settler/army use. The disconnected Palestinian villages had to start a second parallel road network, transforming pristine Wadis into noisy, clogged arteries except for the days of storm floods that turned local Wadis into violent torrents.

Israel's closure regime cut the villages off the main roads and created a new underreported environmental hazard - wild solid waste dump sites in natural Wadis. Palestinian trucks resorted to dumping their loads along and into the next Wadi, the bulk of which was construction waste, besides domestic waste, machines, carcasses and, due to the lack of treatment plants, raw sewage. Israel developed its own wild West Bank garbage piles but on a much larger scale, rapidly filled with the waste from settlers and Israeli communities across the Green Line ${ }^{2}$. The waste at times is toxic, containing glue, solvents and asbestos (Rinat 2008), the practice systematic: "The ministry estimates that more than half of the waste brought to the pirate transfer stations ends up in the West Bank, while the remainder is dumped into streams and vacant lots" (Rinat 2007). The main reasons seem to be convenience and costs ${ }^{3}$. The difference to Palestinian dumps is that Israel uses more centralised collection points with a multiple drop rate.

\section{RUNOFF GENERATION - CONCEPTS AND MEASUREMENTS}

Figure 1 shows the location of nine raingauges, four runoff gauges in road culverts (bridges), and three pressure divers in Wadi gravels (Fig. 1), distributed over the up-, mid- and downstream of Wadi Natuf. This unprecedented network density in the West Bank covers all major geological strata, land forms and climatic zones and records mostly in 5-min steps or in event mode.

On average, each year had approx. one very strong runoff event with $>100000 \mathrm{~m}^{3}$ net outflows near Ne'alin, mostly in early February to mid March. All together, 32 runoff events were monitored, the bulk of which $(13)$ were very small $\left(<1000 \mathrm{~m}^{3}\right)$ and eight were small $\left(<10000 \mathrm{~m}^{3}\right)$.

\footnotetext{
${ }^{2}$ Initially, this transfer of garbage even bore the seal of official approval. "Israel has decided to transfer [10 000 tons of] garbage [per month] beyond the Green Line and dump it in the West Bank for the first time since 1967." and "Transferring the Israeli garbage to Samaria [the northern West Bank] will bring the company a profit of NIS 6 per ton, totalling some NIS 60000 a month.” (Ratner 2005).

${ }^{3}$ As an Israeli contractor explained Haaretz: "In the Negev it costs [the building contractor] NIS 1000 to dump waste, and here you can dump it for free, or pay just NIS 100 per truck." (Hass, 29 Nov. 2007).
} 

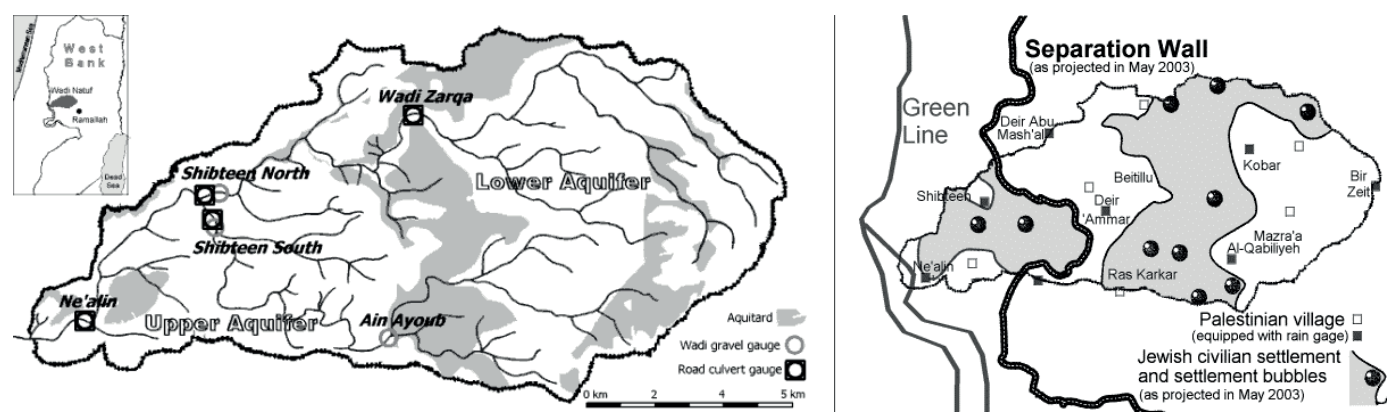

Fig. 1 Wadi Natuf overview maps. Left: drainage, aquifers and runoff gauging sites; right: villages (with tipping buckets), settlement clusters and envisaged annexation zones. Note: On 30 May 2003, Israeli newspaper Ma'ariv presented the route of the separation wall and the settlement clusters earmarked for de facto takeover. Shibteen and Ne'alin would have fallen into no-man's land behind the wall. After international protests and the ICJ ruling against the Israeli wall in the midst of the West Bank, its route was temporarily repositioned. Not all of the settlement clusters have been established, yet the map gives a good impression of their continuous expansion and the ultimate goal of land control.

Table 1 Land forms - runoff sensitive land characteristics along regions in Wadi Natuf.

\begin{tabular}{|c|c|c|c|}
\hline factors & $\begin{array}{l}\text { Upper Wadi Natuf } \\
\text { East }\end{array}$ & $\begin{array}{l}\text { Central Wadi Natuf } \\
\text { Middle }\end{array}$ & $\begin{array}{l}\text { Lower Wadi Natuf } \\
\text { West }\end{array}$ \\
\hline Geography & Eastern highlands & Central hills and plains & Western foothills \\
\hline $\begin{array}{l}\text { Topography, relief } \\
\text { Relief }\end{array}$ & $\begin{array}{l}600->900 \mathrm{~m} \text { a.m.s.l. } \\
\text { steep slopes, terraces }\end{array}$ & $\begin{array}{l}400-600 \mathrm{~m} \text { a.m.s.l. } \\
\text { gentle hills, some plains \& terraces }\end{array}$ & $\begin{array}{l}<200-400 \text { m a.m.s.l. } \\
\text { gentle slopes, big plains, no terraces }\end{array}$ \\
\hline Hydrostratigraphy & Lower Aquifer & Middle Aquitard & Upper Aquifer \\
\hline Soil class, thickness & terra rossa $30-90 \mathrm{~cm}$ & $\begin{array}{l}\text { terra rossa, pale rendzina } 45-120 \\
\mathrm{~cm}\end{array}$ & barren rock, terra rossa $0-70 \mathrm{~cm}$ \\
\hline Vegetation cover & $\begin{array}{l}\text { olive, arable/natural } \\
\text { vegetation, grassland }\end{array}$ & $\begin{array}{l}\text { olive, arable/ natural vegetation, } \\
\text { grassland, forest }\end{array}$ & $\begin{array}{l}\text { grassland/barren (olives, arable/ } \\
\text { natural vegetation) }\end{array}$ \\
\hline Land cover, indexed & $1,2,3$ & $2,3(1,4)((5))$ & $1(2,3)$ \\
\hline Active agriculture & none & rainfed, complex cultivation & none \\
\hline Rainfall (relative) & high & middle to high & low to middle \\
\hline Runoff generation & \pm & + & \pm \\
\hline
\end{tabular}

Land forms were classified after the 'Land Cover Map' generously provided by LRC (2004) as: (1) grass-land with scrubs, barren rock or sclerophyllous vegetation, (2) olive groves, (3) arable land, but currently under natural vegetation, (4) forests \& transitional woodlands, (5) non-irrigated complex cultivation.

Runoff here is understood to depend on two main factors. Temporally, the amount of prewetting of soils and hence the total volume of precipitation is to be considered alongside the rainfall intensities during and shortly before the onset of storm floods. Precipitation rates of $>40 \mathrm{~mm} / \mathrm{d}$ occur in almost every season, reaching up to $86 \mathrm{~mm} / \mathrm{d}$ (average area rain on 2 April 2006). Almost every day with $>20 \mathrm{~mm}$ of rain led to a measurable runoff event. Table 2 shows the rainfall prior to an event, on the day of onset and one day later. Spatially, relief, soils, geology and land use are the governing non-climatic factors. These characteristics are combined here as "land forms". Notably, in Wadi Natuf, the four factors are highly correlated. Lithostratigraphy changes along the rainfallelevation gradient; soil type and thickness can be attributed to these zones. Natural vegetation cover and Palestinian land use still follows these lines almost strictly. Table 1 shows the spatial distribution of different runoff-governing land forms, albeit under "natural" traditional conditions, prior to their recent anthropogenic transformation by society and conflict.

\section{LINKAGES - RESULTS}

Figure 2 shows the area shares of land forms, with $<5 \%$ built-up areas and only $1.5 \%$ non-irrigated agriculture (centre). Only Wadi Zarqa has agriculture, irrigated by local perched springs, $2-3$ ha $(<0.02 \%)$. Olive groves and arable land combine to $\sim 40-45 \%$, and are readily usable for agriculture if water is not a limiting factor. Three main Wadi sections are differentiated: An upstream eastern highland section (Fig. 1) over the Lower Aquifer (Upper Albian Beit Kahil formation), with 
grassland, olives and arable land; a middle section of the northern and southern Wadi branches, until their confluence near Shibteen (Fig. 1(a)) and located over the middle aquitard or the lower parts of the Upper Aquifer (Upper Cenomanian Hebron and Bethlehem formations), has mixed land forms; the combined lower Western drainage section runs over the Upper Aquifer (Turonian Jerusalem formation) until the Green Line (Ne'alin) and is dominated by grassland.

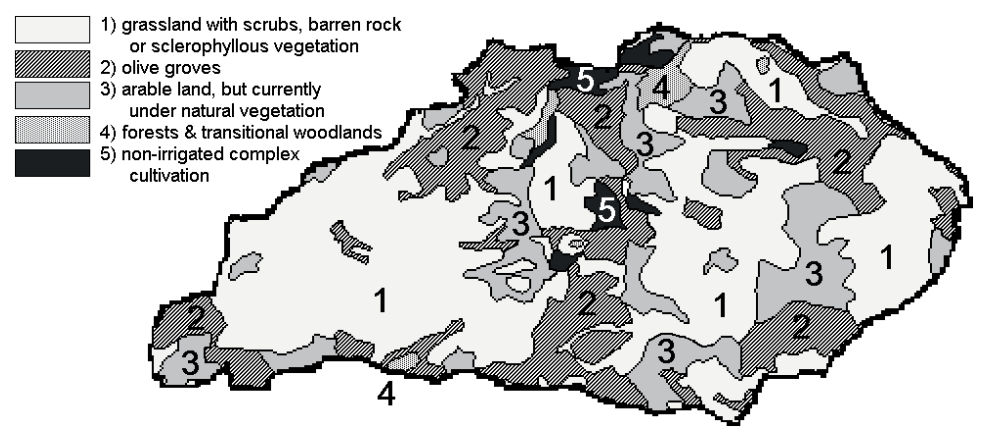

Fig. 2 Simplified land forms map of Wadi Natuf (modified after LRC 2004).

\section{Upstream Wadi Natuf}

The upstream part of the northern branch (Wadi Zarqa gauge) is affected slightly by encroaching settlements from the north and east. Upstream Wadi Zarqa, the land use types are mostly olives, arable but currently not cultivated land, and some coniferous forests and woodlands. Here, only the arable land has a certain tendency to runoff generation. The strongly karstified Beit Kahil formations of the Lower Aquifer further inhibit runoff. All the forests and half of the Olive groves lie in the zone of encroaching settlement annexation, running north-south in a 3-6 km wide strip through the upper/middle Wadi Natuf (Fig. 2). But until now, these plans have not fully materialised and Palestinians are still able to maintain many of their terraces. Throughout the measurement period, only two very strong events were observed, with $327600 \mathrm{~m}^{3}$ runoff (February 2005) and $104700 \mathrm{~m}^{3}$ runoff (March 2010), respectively.

A considerable portion of the Southern branch in its upstream part between Ein Ayoub gauge and the Eastern boundary is underlain by the regional middle aquitard. Slopes are gentler and olives restricted to the top and bottom sections. Scrubby grasslands dominate over potentially arable land under natural vegetation. Near Ein Ayoub gauge, yellow marl (upper Yatta formation) crops out in the Wadi and the lowest Natuf runoff threshold was observed here. Almost every season saw some very strong runoff events - regularly triggered first in this area. It is in this area where the illegal settlers of Talmun, Dolev, Horesh and Nakhliel succeeded to create one uninterrupted settlement bubble, off-limits to any Palestinian presence. Only rarely can farmers, aided by Israeli peace groups, obtain 'permits' to enter their private land to harvest some minimum amounts of their olives. These few hours annually leave no time for ploughing and weeding the terraces, usually carried out twice, after harvest and in spring. Consequently, the ancient olive groves are no longer tended and 'nature' takes back these terraces. As their walls crumble and scrub, weed and bushes rapidly take over this ancient cultural landscape, runoff is enhanced.

\section{Midstream Wadi Natuf}

Midstream Natuf stretches from Wadi Zarqa and Ein Ayoub gauges to the confluence of the two Wadi branches, near Shibteen, mostly over the outcrops of lower part of the Upper Aquifer. In its upper, eastern part, strong Wadi losses were observed. Transmission losses in the northern branch are remarkable (Table 2) and a main reason for the low overall outflow rates from Wadi Natuf (only one major event, February 2005). Throughout the observation period, flow rates remained well below the peak levels reported in the previous literature; Ettinger (1996) had tried to retroactively reconstruct peak floods events of the exceptionally rainy winter 1991/92, claiming runoff rates of up to $>4 \mathrm{~m}^{3} \mathrm{~s}^{-1} \mathrm{~km}^{2}$. The Southern branch has more run-on from upstream and lower Wadi losses 
(more major events than other sites; peak flood, end of January 2008, Table 2). In late winter to early spring, some minor springs upstream of the gauge keep the Wadi flowing.

Notably, human influence is felt here as well. The northern branch is particularly affected by waste dumping. However, time series data reveal locally very variable impact on flow transmission and losses. Near Shibteen in Wadi Hamameh (northern branch) total transmission losses seem to have reduced since 2004/05, possibly due to a clogging of the naturally well-sorted coarse gravel fill. Somewhat inconclusive, the result requires further site-specific investigation.

A third human impact concerns water quality in the deep, yet highly karstic aquifers, with travel and recharge times of weeks only, as monitored in Shibteen borehole \#2. In 2011, Israeli authorities suddenly shut down Shibteen \#4, the only supply well in the entire governorate - claiming that they had found hazardous groundwater pollution levels, but without sharing the laboratory results. Parallel Palestinian testing remained inconclusive. The case remains open and Palestinians fear for the worst (PWA 2012).

Table 2 Major annual runoff events at the four Wadi Natuf gauging stations (road culverts and bridges). Cumulative amounts of event flow in $\mathrm{m}^{3}$. In brackets: peak discharge rates in $\mathrm{m}^{3} / \mathrm{s}$. Daily rate of area rainfall, one day prior, during and after the onset of the event. Incomplete event measurements are not listed.

\begin{tabular}{|c|c|c|c|c|c|c|c|}
\hline $\begin{array}{l}\text { Event period } \\
\text { Start - end }\end{array}$ & $\begin{array}{r}\text { Wadi Zarqa } \\
Q_{\text {cum }}\left(Q_{\max }\right) \\
\mathrm{m}^{3}\left(\mathrm{~m}^{3} / \mathrm{s}\right)\end{array}$ & $\begin{array}{r}\text { Shibteen-North } \\
\mathrm{Q}_{\text {cum }}\left(\mathrm{Q}_{\max }\right) \\
\mathrm{m}^{3}\left(\mathrm{~m}^{3} / \mathrm{s}\right)\end{array}$ & $\begin{array}{r}\text { Shibteen-South } \\
\mathrm{Q}_{\text {cum }}\left(\mathrm{Q}_{\max }\right) \\
\mathrm{m}^{3}\left(\mathrm{~m}^{3} / \mathrm{s}\right)\end{array}$ & $\begin{array}{r}\text { Ne'alin bridge } \\
\text { Q }_{\text {cum }}\left(\mathrm{Q}_{\max }\right) \\
\mathrm{m}^{3}\left(\mathrm{~m}^{3} / \mathrm{s}\right)\end{array}$ & $\begin{array}{c}-1 \text { day } \\
\mathrm{P}_{-1} \\
\mathrm{~mm} / \mathrm{d}\end{array}$ & $\begin{array}{l}\text { onset } \\
\mathrm{P}_{\text {onset }} \\
\mathrm{mm} / \mathrm{d}\end{array}$ & $\begin{array}{c}+1 \text { day } \\
\mathrm{P}_{+1} \\
\mathrm{~mm} / \mathrm{d}\end{array}$ \\
\hline $15-16$ Feb 2004 & n.m. (-) & $36(0.03)$ & $34550(1.2)$ & $3020(0.30)$ & 28 & 29 & $<1$ \\
\hline 5-9 Feb 2005 & $328000(7.7)$ & $124000(3.40)$ & $142000(3.2)$ & n.m. (7.00) & 22 & 50 & 45 \\
\hline 2-4 Apr 2006 & $18330(2.1)$ & $17900(1.50)$ & $173000(5.1)$ & $243000(6.60)$ & 13 & 96 & $<1$ \\
\hline 15-18 Mar 2007 & $14310(0.5)$ & $28(0.001)$ & $13700(0.6)$ & $4640(0.40)$ & 42 & 44 & 13 \\
\hline 29 Jan-1 Feb 2008 & $54560(1.5)$ & $61100(2.30)$ & $355000(6.9)$ & $688000(11.5)$ & $<1$ & 40 & 58 \\
\hline 28 Feb-4 March 2009 & $45950(5.1)$ & n.m. $(-)$ & n.m. (-) & $504000(19.4)$ & 41 & 70 & 37 \\
\hline 27 Feb-1 March 2010 & $105000(4.4)$ & n.m. (-) & n.m. (-) & n.m. (-) & 68 & 44 & 35 \\
\hline
\end{tabular}

$\mathrm{Q}_{\text {cum, }}$ cumulative event flow; $\mathrm{Q}_{\max }$, peak discharge during event; $\mathrm{P}_{-1}$, rain one day prior; $\mathrm{P}_{\text {onset, }}$, rain at the first day; $\mathrm{P}_{-1}$, rain one day after onset of the event

\section{Lower Wadi Natuf}

The lower section overlies the Turonian karstic Jerusalem formation (Top Upper aquifer). Grassland with scrubs and barren rock dominate over sporadic olives. This area is also affected by the separation barrier. A new settler highway cuts into the hills and below, Israel opened a large quarry. The debris of both is disposed into and along the lower Wadi Natuf, walling-in the Wadi course over $3 \mathrm{~km}$. The biggest Israeli dump site lies near Ne'alin (Hass 2007), towering five storeys high above the Wadi. Under more natural conditions until 2003/04, this section showed high transmission losses of up to $>90 \%$ during medium scale events (February 2005, Table 2). On the other hand, during very strong events, infiltration rates pale against Wadi flow rates. But for several years now, the Wadi is in desolate conditions, littered all the way, in some sections also by Palestinian wild garbage disposal. Veritable lakes form after seasonal floods. Peak event transmission losses are now strongly reduced, especially when comparing Ne'alin with Shibteen South over time: in the past, Ne'alin had only $40 \%$ higher flows than Shibteen South alone (April 2006); now, Ne'alin has almost double the flow rates than Shibteen South $(2008,2009$, Table 2).

\section{CONCLUSIONS AND RECOMMENDATIONS}

The occupied West Bank represents a unique case where hydrological features are not only manifest as a response to general human intervention, but can be attributed to, and differentiated by, two sides under political conflict. It should be noted that given the severe and ever deepening Palestinian water crisis (see World Bank 2009, Koek 2013) changes in runoff patterns, spatial and temporal distribution may be the least of their problems; but it is worth noting that both the general crisis, and the changing runoff patterns are underlain by the same set of social and political drivers that steer the entrenched conflict. The main unresolved problems of the occupied Palestinians - their lack of 
sovereignty and control over land and water resources, stand in the way of addressing the environmental problems and basic human needs of a population held without political rights. During the past half century Israel's military occupation prevented any new Palestinian well drilling in the Western Aquifer, the by-far largest, freshest and most productive of all basins.

Several conclusions can be stated here. A distinct hydrological feedback from both Palestinian and Israeli human activities could be observed. Runoff is enhanced by abandoned and crumbling terraces in the steep mountain slopes. Relentless, largely uncontrolled construction acts similarly. The mushrooming dump sites have led to locally variable hydrological responses that depend on the local setting of Wadis, land forms, underlying geology and typical event patterns. Most Wadis showed an increase in runoff and a lowered threshold, but with some notable exceptions that require further research.

This may open a new field of research beyond the classical hydrological investigations, which is highly relevant when targeting the little understood interaction between society, conflict and hydrology. So far, only a decade of observations exist. But a new trend with new underlying social and political reasons already emerges as a pattern. This understanding is to be deepened by future monitoring with a focus on three areas: (a) understanding the changing spatial factors that rule runoff generation, (b) quantifying these responses through consolidated field instrumentation and measurement routines, and (c) well focused local measurements of the water quality in floods, aquifers and the unsaturated zone may soon become highly relevant.

Removal of the wild dump sites and re-activation of the ancient terraces against mushrooming settlement construction and encroachment would constitute a formidable protection measure against increasing trends of storm runoff. But as already mentioned, the likelihood of such measures being taken is not merely a technical-scientific matter of well-informed hydrological science, but also goes to the heart of the political conflict in particular, and societal change in general.

\section{REFERENCES}

Ettinger, H. (1996) Spatial analysis of extreme storms and floods in the Ayalon-Yarqon catchment. PhD Thesis, Hebrew University, Jerusalem.

Hareuveni, E. and Stein, Y. (eds) (2011) Dispossession and Exploitation Israel's policy in the Jordan Valley and Northern Dead Sea. B'Tselem, Jerusalem.

Hass, A (2007) Israel's dumping ground. Haaretz, 29 November 2007. Available from: http://www.haaretz.com/hasen/objects/pages/PrintArticleEn.jhtml?itemNo=929673 (accessed 29 November 2007).

Koek, E. (2013) Water for one people only. Al-Haq, Ramallah - West Bank.

Kronaveter, L., Shamir, U. and Kessler, A. (2001) Water-sensitive urban planning modelling on-site infiltration. J Water Resour Plann. and Management, 31(3-4), 78-88.

Land Research Center (2004) Land Cover Mapping. Digital version of satellite imagery based GIS maps (scale 1: 150,000) Arab Studies Society, El-Bireh (unpublished).

Lange, J. (2003) Runoff generation from successive simulated rainfalls on a rocky, semi-arid, mediterranean hillslope. Hydrological Processes doi: 10.1002/hyp.

Lange, J. (2004) Final Report: The impact of urbanization on integrated drainage basin hydrology and water resources, West Bank and Israel. Universität Freiburg i.Br; Abt. Hydrologie.

Lange, J. et. al. (2002) Tracer techniques in sprinkling tests to study runoff generation in a rocky Mediterranean karst environment. Freiburger Schr. z. Hydrol., Inst. Hydrol., Univ. Freiburg i.Br. 1-13.

Lange, J. et al. (2003) Tracers for runoff generation studies in a Mediterranean region: compariosn of different scales. In: Hydrology of Mediterranean and Semi-arid Regions (Proceedings of an international symposium held at Montpellier, April 2003), (ed. by E. Servat et al.). IAHS Publ. 278, 117-123. IAHS Press, Wallingford, UK.

Ma'ariv (2003) Projected route of the separation barrier. Ma'ariv, 30 May 2003.

PWA (2012) Oral communication. With Eng. Abdelghafour, D.; Palestinian Water Authority - El-Bireh (12 September 2012).

Ratner, D (2005) Israel to dump 10,000 tons of garbage a month in the West Bank. Haaretz, 4 April 2005. Available from: http://www.haaretz.com/hasen/pages/ShArt.jhtml? itemNo=560433 (accessed 4 April 2005).

Rinat, Z. (2007) Just dump it anywhere. Haaretz, 28 November 2007. Available from: http://www.haaretz.com/hasen/objects/pages/PrintArticleEn.jhtml?itemNo=928778 (accessed 28 November 2007).

Rinat, Z. (2008) Gov't admits: Building debris still dumped in W. Bank. Haaretz, 2 March 2008. Available from: http://www.haaretz.com/hasen/objects/pages/PrintArticleEn.jhtml?itemNo=959626 (accessed 2 March 2008).

Steinmann, A (2010) Runoff generation in Mediterranean areas. PhD Thesis, Universität Freiburg i.Br; Abt. Hydrologie, Freiburg i.Br., Germany.

SUSMAQ (2002) Compiled Base Data for the Numerical Groundwater Flow Model of the Western Aquifer Basin, Volume 1 General Background. Report No.: SUSMAQ-MOD Report No. \#07 V0.4. Sustainable Management for the West Bank and Gaza Aquifers, Palestinian Water Authority (Palestine) and University of Newcastle upon Tyne (UK) 01-306.

World Bank (2009) Assessment of Restrictions on Palestinian Water Sector Development - Sector Note. World Bank Report No. 47657-GZ; April 2009, Washington 1-136. 